\title{
COMPLETE ATRIOVENTRICULAR SEPTAL DEFECTS DENGAN POLISITEMIA SEKUNDER
}

\author{
Bun Yurizali ${ }^{1}$, AM Hanif ${ }^{2}$
}

\begin{abstract}
Abstrak
Atrioventricular septal defect (AVSD) adalah kelainan berupa defek pada septum atrioventrikular (AV) di atas atau bawah katup AV, disertai kelainan katup AV; terjadi akibat pertumbuhan yang abnormal dari endokardial cushion pada masa janin. AVSD mewakili 4\% sampai 5\% bawaan cacat jantung. Dilaporkan seorang pasien laki-laki 20 tahun dengan keluhan sesak nafas saat beraktivitas dan berkurang dengan istirahat, disertai bibir dan kuku jari yang membiru, sakit kepala hilang timbul, muka kemerahan, demam, lemah letih lesu dan dada rasa berdebar-debar. Adanya sianosis, kulit kemerahan, Konjungtiva hiperemis, peningkatan JVP, hepatojugular refluks, bentuk dada abnormal. Bunyi jantung reguler, terdengar bising sistolik di RIC VI, blowing, grade 4/6, punctum maximum di apeks, penjalaran ke Axilla. Bising sistolik di RIC V linea strenalis dektra, grade 4/6, blowing punctum maksimun di RIC V linea sternalis dektra. Pada pemeriksaan laboratorium didapatkan polisitemia. Pada rontgent dada terdapat kardiomegali, dari ekokardiografi adanya CAVSD, hipertensi pulmonal Moderate-severe, Left arch, fungsi RV yang menurun. Pada pasien dilakukan prosedur flebotomi untuk mengurangi kepekatan darah. Pengobatan hipertensi pulmonal pada pasien ini adalah dengan pemberian diuretik dan dorner.
\end{abstract}

Kata kunci: Atrioventricular septal defect, polisitemia sekunder, hipertensi pulmonal

\begin{abstract}
Atrioventricular septal defect (AVSD) is a defect on atrioventricular (AV) septum on top of or below AV septum which occurs as a result from abnormal growth of endocardial cushion in fetus. AVSD represents $4 \%$ to $5 \%$ congenital heart disease. We reported a male patient aged 20 years with breathlessness happened when doing activities, and decreased after he took some rest also accompanied by cyanosis at mouth and nails. Patient also had headache, plethorea, fever, fatigue and palpitation. There were cyanosis, hiperemic conjunctiva, elevated JVP, hepatojugular reflux and abnormal chest. Heart sound was regular, systolic murmur was found at ICS VI, blowing, grade 4/6, maximum punctum at apex with with spreading to axilla. Systolic murmur also found at ICS $V$ linea sternalis dextra, blowing, grade 4/6, blowing maximum punctum at ICS $V$ linea sternalis dextra. From laboratory result was found poisitemia. Chest $X$ Ray showed cardiomegaly, and Echocardiography showed CAVSD, pulmonary hypertension moderate-severe, left arch, reduced RV function. Phlebotomy was done to the patient to decrease blood hyperviscocity. To treat pulmonary hypertension, we gave diuretic and dorner to the patient.
\end{abstract}

Keywords: atrioventricular septal defect, secondary polycythemia, pulmonal hypertension

Affiliasi penulis: 1. Fakultas Kedokteran Universitas Baiturrahmah Padang, 2. Subbagian Kardiologi Bagian IImu Penyakit Dalam Fakultas Kedokteran Universitas Andalas/RSUP M Djamil Padang. Korespondensi: Bun Yurizali, Email:ibun.dr@gmail.com Telp: +6285363449597

\section{PENDAHULUAN}

Congenital Heart Defect (CHD) atau kelainan jantung kongenital merupakan kelainan fetus yang paling sering terjadi diperkirakan 4/1000 sampai 50/1000 kelahiran hidup dan sekitar 30/1000 bayi yang baru lahir. Atrioventricular septal defect (AVSD) adalah kelainan berupa defek pada septum atrioventrikular (AV) di atas / di bawah katup AV, disertai kelainan katup AV; terjadi akibat pertumbuhan yang abnormal dari endokardial cushion pada masa janin. Insiden AVSD 348:100.000 mewakili 17,4\% dari semua 
kelainan jantung. Berbagai klasifikasi telah digunakan untuk menggambarkan AVSD, sehingga sering membingungkan. Namun sekarang digunakan kesepakatan membagi AVSD menjadi dua bentuk, yaitu parsial bila hanya ada atrial septal defect (ASD) primum tanpa ventricular septal defect (VSD), dengan dua katup AV (mitral dan trikuspid) yang tidak menutup dengan sempurna sehingga terdapat mitral regurgitasi. Komplit bila ada defek atau lubang pada septum atrium dan ventrikel. Pada AVSD komplit terdapat lubang besar ditengah jantung dipertemuan antara dinding bagian atas dan bawah ruang jantung terdiri dari dua katup terpisah di kiri dan kanan, salah satu katup berada antara ruang atas dan bawah. Seringnya katup ini tidak menutup dengan sempurna). ${ }^{1}$

Gejala klinis dari AVSD tergantung pada defek yang terjadi. Gejala congestive heart failure dapat terjadi pada dua bulan pertama umur bayi. Beberapa dengan CAVSD tidak akan berkembang menjadi congestive heart failure. Hal ini terjadi pada beberapa kasus karena sel otot pada arteri kecil paru menjadi besar dan konstriksi mencoba untuk melindungi paru dari aliran tambahan dan tekanan tinggi yang disebabkan oleh AVSD. Peningkatan resistensi pembuluh darah paru sangat efektif untuk mencegah gejala dan tanda congestive heart failure dengan meminimalisir jumlah shunt dari kiri ke kanan, dan bisa menyebabkan darah dengan kadar oksigen rendah mengalir dari ventrikel kanan ke ventrikel kiri dan menuju ke seluruh tubuh tanpa membawa oksigen. Hal ini menyebabkan sianosis dan terjadinya hipoksia di jaringan seluruh tubuh. Diagnosis AVSD ditegakkan dari keadaan klinis seperti sianosis, congestive heart failure, bunyi jantung 2 di pulmonal (P2) meningkat dan adanya bising sistolik. Dari EKG didapatkan PR interval memanjang, Axis deviasi ke kanan, Right bundle branch block partial. Chest X- Ray didapatkan cardiomegaly, corakan vaskular paru meningkat, left aortic arch. Echocardiografi didapatkan hilangnya septum atrioventrikular, konfigurasi abnormal katup atrioventrikular, disporposi left ventricular, inlet outlet, posisi muskulus papilaris ventrikel kiri abnormal. ${ }^{2}$

Penatalaksanaan meliputi terapi medika mentosa meliputi terapi gagal jantung dan terapi infeksi paru sedangkan terapi intervensi bedah diindikasikani tergantung bentuk AVSD. Tetapi jika tanda gagal jantung kongestif muncul, koreksi pembedahan harus dilakukan sesegera mungkin. Tatalaksana dibedakan berdasarkan ada tidaknya gagal jantung dan tipe AVSD. ${ }^{2}$

Hipertensi pulmonal adalah peningkatan tekanan arteri pulmonal lebih dari $25 \mathrm{mmHg}$ pada keadaan istirahat atau lebih dari $30 \mathrm{mmHg}$ pada saat latihan. Hipertensi arteri pulmonal bisa berhubungan dengan berbagai keadaan seperti penyakit jaringan ikat, penyakit jantung bawaan dengan shunt dari kiri ke kanan, hipertensi portal dan infeksi human immunodeficiency virus (HIV), obat- obatan dan toksin. Shunt dari kiri ke kanan mencetuskan peningkatan aliran darah ke paru dan meningkatkan tekanan arteri pulmonal. Eisenmenger's syndrome diartikan sebagai defek jantung bawaan yang disebabkan oleh shunt besar dari kiri ke kanan yang mencetuskan penyakit pembuluh darah paru dan hipertensi arteri pulmonal, dengan arah shunt berbalik. ${ }^{3}$

Bila ada hubungan antara jantung kanan dan kiri, darah mengalir dari ruang dengan oksigen rendah ke ruang dengan oksigen tinggi. Sebagai contoh shunting dari atrium kanan ke atrium kiri pada pasien dengan defek septum atrium (ASD) dan hipertensi arteri paru. Pasien yang dulunya asianotik menjadi sianotik. Salah satu cara tubuh mengkompensasi adalah dengan meningkatkan kemampuan darah untuk membawa oksigen dengan meningkatkan jumlah sel darah merah, suatu kondisi yang disebut eritrositosis sekunder, disebut juga sebagai polisitemia. $^{4}$

Polisitemia mengandung arti banyak sel. Hal ini dihubungkan dengan peningkatan jumlah dan volume sel darah merah (eritrositosis) secara bermakna mencapai 6-10 juta $/ \mathrm{ml}$ ditas ambang batas nilai normal dalam sirkulasi darah. Pada kasus penyakit jantung kronis seperti gagal jantung kongestif atau aliran abnormal dari sisi kanan ke sisi kiri jantung yang menyebabkan rendahnya oksigen dalam darah sehingga terjadi hipoksia kronis, polisitemia sekunder merupakan respon fisik yang dibentuk tubuh untuk meningkatkan kapasitas darah membawa oksigen. ${ }^{5}$

\section{KASUS}

Seorang pasien laki-laki 20 tahun dirawat di bangsal Penyakit Dalam RSUP dr. M. Djamil Padang 
dengan keluhan sesak nafas yang meningkat sejak 1 minggu sebelum masuk rumah sakit. Sesak nafas saat beraktivitas dan berkurang dengan istirahat, sesak tidak dipengaruhi suhu dan makanan dan tidak berbunyi menciut Sesak nafas disertai bibir dan kuku jari yang membiru. Keluhan lain berupa sakit kepala hilang timbul, muka kemerahan, demam, lemah letih lesu dan dada rasa berdebar-debar.

Pada pemeriksaan fisik didapatkan adanya tekanan darah 100/70 $\mathrm{mmHg}$, frekuensi nadi 82 $\mathrm{x} /$ menit, reguler, pengisian kecil dan frekuensi nafas $26 \mathrm{x} /$ menit, sianosis $(+)$, kulit kemerahan, Konjungtiva hiperemis, peningkatan JVP $5+3 \quad \mathrm{cmH}_{2} \mathrm{O}$, hepatojugular refluks (+), bentuk dada abnormal. Bunyi jantung reguler, terdengar bising sistolik di RIC VI, blowing, grade 4/6, punctum maximum di apeks, penjalaran ke Axilla. Bising sistolik di RIC V linea strenalis dektra, grade 4/6, blowing punctum maksimun di RIC V linea sternalis dektra, tidak ada penjalaran suara. Dari anggota gerak didapatkan clubbing finger $(+)$, schamroth's window sign (-), akral sianosis $(+)$.

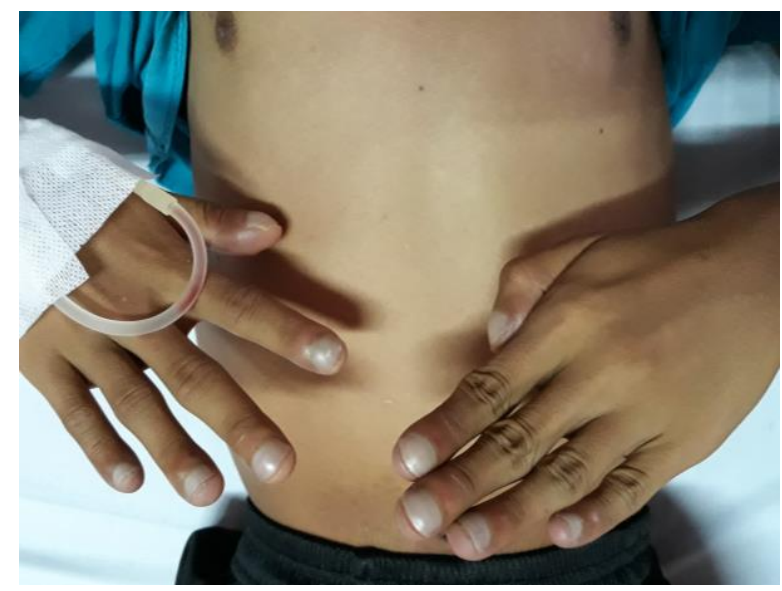

Gambar 1. Jari tabuh

Pada pemeriksaan laboratorium didapatkan

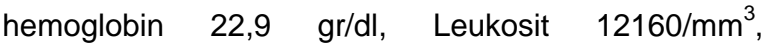
hematokrit $68 \%$, trombosit 121.000/mm3, Diffcount 0/2/1/87/10/0, LED 87 mm/jam. Gambaran EKG didapatkan kesan RAD, RVH, RBBB, iskemik miokard. Hasil ekspertise X-Ray dada adanya Kardiomegali dengan peningkatan corakan vascular.

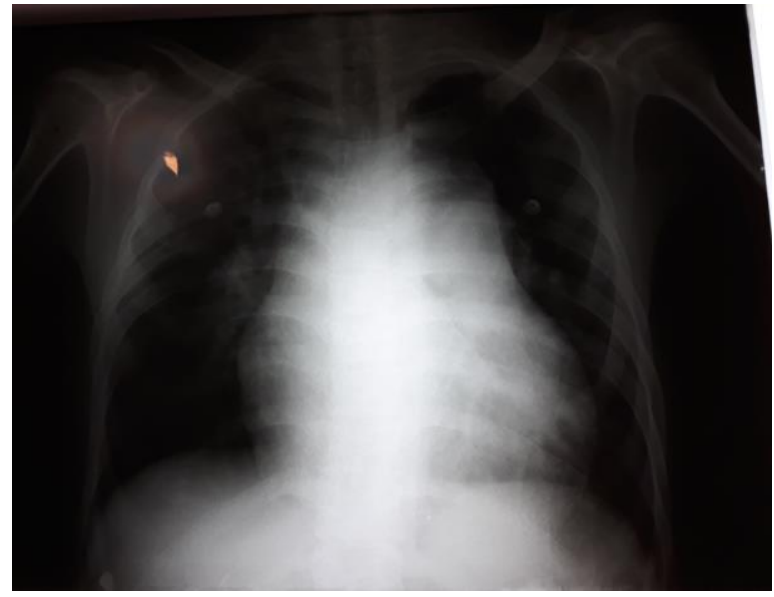

Gambar 2. Foto X-ray dada

Pada pemeriksaan Ekokardiografi didapatkan adanya ejeksi fraksi $65 \%$, CAVSD, hipertensi pulmonal Moderate-severe, Left arch, fungsi RV yang menurun. Pada pasien dilakukan prosedur flebotomi untuk mengurangi kepekatan darah ditambah dengan Aspilet $1 \times 80 \mathrm{mg}$. Tindakan pengobatan hipertensi pulmonal pada pasien ini adalah dengan pemberian diuretik dan dorner (beraprost) $3 \times 40 \mathrm{mcg}$ serta ramipril $1 \times 2,5$ mg.

\section{PEMBAHASAN}

Telah dirawat pasien laki-laki umur 20 tahun dengan diagnosis Complete Artrioventriculer Septal Defect (CAVSD) dengan hipertensi pulmonal dan Eisenmenger Syndrome dengan polisitemia sekunder ec CAVSD. Artrioventriculer Septal Defect merupakan suatu keadaan dimana tidak terbentuknya struktur septum atrioventrikuler yang normal sehingga atrioventriculer junction menyatu. Pada complete AVSD, tidak adanya bagian inferior septum atrium dan bagian posterior septum ventrikel. Terdapat common $A V$ valve, sehingga seluruh bagian tengah jantung hilang. Diagnosis CAVSD dapat ditegakan melalui anamnesis, pemeriksaan fisik, chest x-ray, elektrokardiogram dan echocardiografi. ${ }^{2}$ Dari anamnesis dan pemeriksaan fisik pada pasien ini didapatkan ada nya gejala penyakit jantung bawaan sianotik yaitu pasien mempunyai riwayat sesak, kebiruan, sering pingsan pada masa kanak - kanak, kebiruan pada lidah dan bibir. Sianosis pada CAVSD 
merupakan sianosis sentral yang nampak pada bibir dan mukosa mulut. Sianosis merupakan warna kebiruan pada mukosa yang disebabkan oleh terdapatnya lebih dari $5 \mathrm{mg} / \mathrm{dl}$ hemoglobin tereduksi pada sirkulasi. Pada CAVSD akibat shunt yang terjadi dapat menyebabkan darah vena masuk ke sirkulasi arteri. Pada bayi dengan CAVSD gagal jantung dapat terjadi dalam beberapa bulan awal kehidupan. Pada pasien ini didapatkan gejala dan tanda gagal jantung berupa sesak saat aktivitas, tanda peningkatan tekanan vena jugular, hepatojugular refluks dan tanda kardiomegali. Ada atau tidak nya gejala gagal jantung pada pasien CAVSD juga menentukan pada terapi terutama terapi pembedahan. Pasien ini terdiagnosis CAVSD pada umur kanak - kanak pada saat terdiagnosis pasien telah sampai pada keadaan gagal jantung dan hipertensi pulmonal sehingga pada pasien ini operasi tidak mungkin dilakukan lagi akibat defek yang luas dan keadaan yang tidak memungkinkan untuk toleransi operasi.
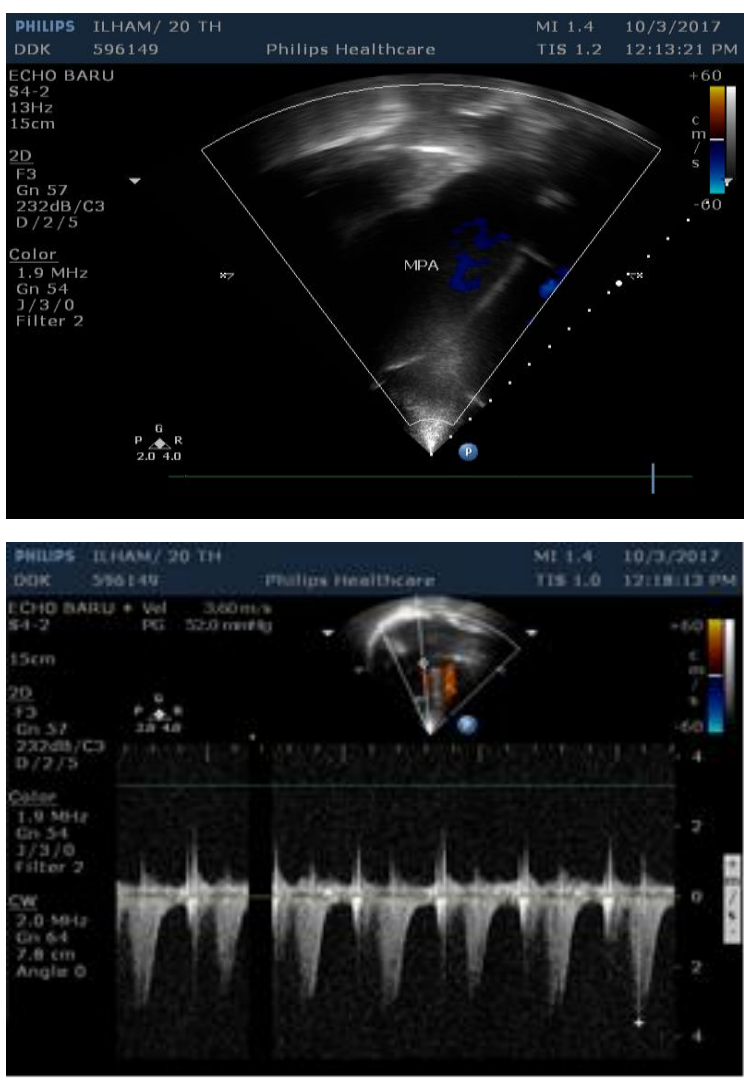

Gambar 3. Ekokardigrafi

Operasi idealnya dilakukan pada CAVSD pada umur 3 bulan sebelum umur 6 bulan untuk menghindari terjadinya hipertensi pulmonal. Sebuah penelitian menyebutkan bahwa angka kematian pada operasi dini kurang dari $10 \%$. Tidak ada perbedaan kematian saat operasi antara bayi dengan berat badan lebih dari 5 kilogram dengan bayi yang berat badan nya kurang dari 5 kilogram. ${ }^{6}$ Pada pasien ini untuk gagal jantung diberikan terapi diuretik, ACE inhibitor dan antagonis aldosterone. Gagal tumbuh merupakan salah satu akibat tersering dari penyakit jantung bawaan sianotik CAVSD. Hal ini terjadi akibat terjadi percampuran darah yang kaya akan oksigen dan yang rendah oksigen pada defek di dinding jantung dan katup yang abnormal menyebabkan kebocoran aliran darah ke ruang bawah jantung. Akibatnya jantung bekerja lebih keras, sehingga terjadi pembesaran jantung. Sebagai akibatnya, bayi dengan CAVSD mengalami kesulitan bernafas, jaringan kekurangan oksigen dan bayi tersebut tidak tumbuh dan berkembang dengan normal. ${ }^{2}$ Pada pemeriksaan fisik ditemukan adanya clubbing finger dan bising pansistolik. Hipoksia dan atau peningkatan aliran darah ke jari merupakan faktor penyebab clubbing finger.

Pada hipoksia jaringan yang berlangsung lama faktor pertumbuhan megakariosit dan trombosit tersumbat pada kapiler kuku sehingga merangsang jaringan ikat vaskular. Tanda dari clubbing finger yaitu rasio kedalaman interfalang lebih dari satu, sudut dasar kuku lebih dari 190 derajat dan schamroth's window sign menghilang. Bising pansistolik disebabkan ketika adanya aliran diantara dua kamar yang memiliki perbedaan tekanan yang luas saat sistolik. Perbedaan tekanan terjadi pada awal kontraksi dan berakhir pada pada saat relaksasi hampir selesai.Pasien CAVSD tanpa operasi dapat meninggal pada saat bayi dan yang tetap survive akan berkembang menjadi hipertensi pulmonal dan meninggal dengan eisemenger's syndrome. Pada keadaan CAVSD dengan defek kecil dan regurgitasi katup atrioventrikel minimal tanpa operasi dapat bertahan lebih lama dan $25 \%$ dapat bertahan sampai umur 40 tahun. Menurut Chauhan, pada CAVSD tanpa operasi hanya $4 \%$ yang dapat bertahan sampai usia 5 tahun. ${ }^{6}$ Pada pasien ini sejak terdiagnosis 10 tahun yang lalu tetap dalam keadaan stabil dan terkontrol dengan obat - obatan. Pasien ini telah menunjukan manifestasi hipertensi pulmonal. Shunt dari kiri ke 
kanan mencetuskan peningkatan aliran darah ke paru dan meningkatkan tekanan arteri pulmonal. Gejala dan tanda dari hipertensi pulmonal pada pasien ini adalah berupa sesak nafas, mudah lelah, pingsan, P2 > A2, bising pansistolik di daerah tricuspid, peningkatan tekanan vena jugularis, dari EKG didapatkan RVH dan RAD. EKG mempunyai sensitivitas $55 \%$ dan spesifisitas 70\% untuk menskrinning hipertensi pulmonal. Pada pemeriksaan penunjang radiologi thorax didapatkan adanya kardiomegali dengan peningkatan corakan vascular. Tindakan pengobatan hipertensi pulmonal pada pasien ini adalah dengan pemberian diuretik dan dorner (beraprost) $3 \times 40$ mcg. Beraprost merupakan analog protasiklin. Dalam suatu studi dilaporkan perbaikan kualitas hidup 24 pasien hipertensi pulmonal yang diberikan beraprost dibandingkan dengan 34 pasien dengan terapi konvensional. $^{6}$

Pada pasien ini telah ditemukan tanda Eisenmenger Syndrome. Hasil echokardiokgrafi telah terdapat hipertensi pulmonal dan shunt berbalik arah. Tatalaksana Eisenmenger Syndrome berdasarkan pengalaman klinis dan non spesifik randomized control trial. Plebotomi dengan penggantian isovolume pada pasien dengan gejala hiperviskositas dengan hematokit $>65 \%$ dapat dilakukan. Pemberian diuretik juga bermanfaat pada pasien dengan gejala gagal jantung. ${ }^{7}$

Pada pasien ditemukan adanya polisitemia sekunder karena adanya hipoksia. Respon fisiologis terhadap hipoksia akan meningkatkan eritropoietin yang merangsang sumsum tulang untuk untuk memproduksi sel darah merah. Pada CAVSD ketika terdapat hubungan antara jantung kanan dan kiri, darah mengalir dari ruangan atau pembuluh darah dengan oksigen rendah ke oksigen tinggi. Pasien yang sebelumnya asianotik akan menjadi sianotik. Salah satu cara bagi tubuh untuk mengkompensasinya adalah dengan meningkatkan kemampuan darah untuk membawa oksigen dengan meningkatkan jumlah sel darah merah, sebuah kondisi yang dinamakan dengan eritrositosis atau polisitemia. ${ }^{8}$

Prosedur flebotomi dilakukan pada pasien untuk mengurangi kepekatan darah. Tidak ada studi tertentu yang menetapkan kadar optimal hematokrit pada pasien penyakit jantung bawaan. Panduan praktek klinis terkini melakukan prosedur flebotomi pada pasien polisitemia sekunder ketika menunjukan gejala hiperviskositas untuk menurunkan hematokrit < $65 \%$. Gejala hiperviskositas dapat berupa sakit kepala, konsentrasi kurang, kelelahan, dan perburukan toleransi aktivitas. Pada pasien ditemukan gejala sakit kepala, dan kelelahan, sehingga tindakan flebotomi dilakukan. Tatalaksana flebotomi pada pasien ini tidak seagresif pada polisitemia vera. Setelah tindakan, keluhan pasien berkurang. Selain itu pasien juga mendapatkan obat antiplatelet untuk mengurangi risiko terjadinya trombus. ${ }^{8}$

Pada kasus ini yang paling penting adalah bagaimana edukasi terhadap pasien, mengingat prognosis pada pasien ini bukanlah prognosis yang baik karena pada pasien ini telah terdapat Eisenmenger Syndrome. Angka harapan hidup pada Eisenmenger Syndrome dengan CAVSD lebih rendah. Kematian mendadak pada pasien ini dapat terjadi akibat hemoptysis masif akibat intraparenkim hemoragik, masif pulmonary infark dan diseksi aorta. Pada pasien ini dalam 10 tahun terakhir pasien bisa tetap dalam kondisi stabil dengan tetap rutin kontrol dan mengkonsumsi obat. Maka dari itu nasihat untuk kontrol dan minum obat teratur perlu ditekankan. Batasan aktifitas fisik harus dipatuhi. Keadaan polisitemia pada pasien ini dapat terus berlangsung sebagai respon terhadap keadaaan hipoksi kronis pada pasien ini. Maka kontrol rutin dan pemeriksaan kadar hemoglobin berkala diperlukan, sehingga jika pada keadaan hemoglobin dan hematokrit meningkat tinggi maka prosedur flebotomi bisa jadi dilakukan lagi.

\section{SIMPULAN}

Pasien menderita penyakit jantung bawaan yang berakibat hipoksia. Pasien ini telah menunjukan gejala gagal jantung, hipertensi portal dengan Eisenmenger Syndrome. Pada keadaan ini prognosis tidak terlalu baik. Polisitemia yang terjadi pada pasien ini sekunder akibat respon kekurangan oksigen jangka lama. Edukasi untuk kontrol teratur pada pasien ini sangat dibutuhkan untuk menjaga kondisi stabil 


\section{DAFTAR PUSTAKA}

1. Muresan D, Marginean C, Zaharie G, Stomatian F, Rotar IC. Complete atrioventricular septal defect in the era of prenatal diagnosis. Medultrason.2016:18;500-7.

2. Craig B. Atrioventricular septal defect: from fetus to adult. Heart. 2006;92:1879-85.

3. Hoeper MM, Bogaard HJ, Condliffe R, Frantz R, Khanna D, Kurzyna M, et al. Defenition and diagnosis of pulmonary hypertension. Journal of the American College of Cardiology.2013;62:42-50.

4. Rose SS, Shah AA, Hoover DR, Saidi P. Cyanotic congenital heart disease with sympthomatic erythrocytosis. Journal general internal medicine. 2007;22(12):1775-7.
5. Tefferi A, Barbui T, Polycythemia vera and essential trombocythemia: 2017 update on Diagnosis, risk - stratification, and management. American Journal of Haematology. 2016; 90(2): 95108.

6. Chauhan. Atrioventricular septal defects. Annals of Cardiac Anaesthesia. 2018;21:1-3.

7. Baumgartner, Helmut. ESC guidelines for the management of grown-up congenital heart disease. European Heart Journal. 2010:(31);291557.

8. McMulin MF, Bareford D, Campbell P. Guideline for the diagnosis, investigation and management of polycythaemia/ erythrocytosis. British journal of haematology. 2005;(130):174-95. 